\begin{tabular}{|c|c|c|}
\hline & Int.J.Curr.Microbiol.App.Sci (2021) 10(10): 185-192 & \\
\hline & $\begin{array}{l}\text { International Journal of Current Microbiology and Applied Sciences } \\
\text { ISSN: 2319-7706 Volume } 10 \text { Number } \mathbf{1 0}(\mathbf{2 0 2 1 )} \\
\text { Journal homepage: } \underline{\text { http://www.ijcmas.com }}\end{array}$ & 30 \\
\hline $\begin{array}{l}\text { EXCELLENT } \\
\text { PUBLISHERS }\end{array}$ & & \\
\hline
\end{tabular}

\title{
Genetic Variability, Correlation and Path Analysis Studies in Rabi Sorghum (Sorghum bicolour (L.) Moench) Genotypes
}

\author{
M. S. Nikam*, G. C. Shinde, V. R. Awari, M. S. Shinde and N. S. Kute \\ Department of Agricultural Botany, Pulses Improvement Project, Mahatma Phule Krishi \\ Vidyapeeth, Rahuri, Maharashtra, India \\ *Corresponding author
}

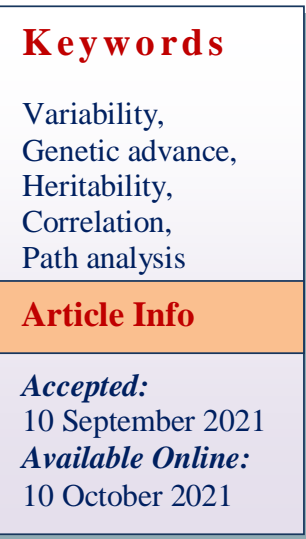

\section{A B S T R A C T}

The forty four promising sorghum genotypes were evaluated for variability, correlation and path analysis for yield and yield contributing characters, at Sorghum improvement Project, Mahatma Phule Krishi Vidyapeeth, Rahuri during Rabi-201920. High estimates of PCV and GCV were observed for traits no. of green leaves per plant at harvest, panicle length $(\mathrm{cm})$, panicle width $(\mathrm{cm})$, panicle weight $(\mathrm{g})$, harvest index and grain yield per plant $(\mathrm{g})$.High estimates of heritability along with high genetic advance were recorded for plant height $(\mathrm{cm})$, no. of green leaves per plant at harvest, panicle length $(\mathrm{cm})$, panicle width $(\mathrm{cm})$, panicle weight $(\mathrm{g}), 1000$ grain weight (g), dry fodder yield per plant (g), harvest index and grain yield per plant (g).Correlation studies revealed a positive and significant association of grain yield with plant height $(\mathrm{cm})$, number of internodes per plant, number of green leaves per plant at harvest, panicle length $(\mathrm{cm})$, panicle width $(\mathrm{cm})$, panicle weight $(\mathrm{g}), 1000$ grain weight $(\mathrm{g})$, dry fodder yield per plant $(\mathrm{g})$ and harvest index at both genotypic and phenotypic level. Harvest index, panicle weight, dry fodder yield per plant, days to maturity and no. of internodes per plant recorded high magnitudes of direct effects accompanied by highly significant correlation with the grain yield at genotypic level, indicating true and perfect relationship between them. Thus suggesting that selection for these traits viz., harvest index, panicle weight, dry fodder yield per plant, days to maturity and no. of internodes per plant will be highly rewarding for improving the grain yield per plant.

\section{Introduction}

Sorghum (Sorghum bicolor (L.) Moench) is one of the world's most significant cereal grain crops, having originated in West Africa between 5000 and 8000 years ago (De Candolle, 1884) and having a secondary origin in the Indian subcontinent. Millions of poor people in Africa and Asia's semi-arid tropics rely on it as a staple diet, and it has the fifthlargest acreage of all cereals. In India, it is grown during both kharif (rainy season from June-October) and rabi (post-rainy season from October-January) seasons for multiple 
uses as a food, feed, fodder and fuel crop. Due to different agro-climatic conditions, the cultivar requirements for these two seasons are silent diverse (Rana et al., 1997). Sorghum is grown on 4.48 million hectares in India, with an annual production of 4.38 million tonnes and a productivity of $1051 \mathrm{~kg}$ per hectare. Maharashtra, the country's leading sorghum producer, with a total area of 21.90 lakh hectares. The total area under cultivation, with an annual production of 18.09 lakh tonnes and a productivity of $826 \mathrm{~kg}$ per hectare. In kharif, 2.80 lakh hectares are planted, with an annual production of 1.77 lakh tonnes and a productivity of $630 \mathrm{~kg}$ per hectare. It is grown on 19.09 lakh hectares during the rabi season, with an annual production of 16.33 lakh tonnes and a productivity of $855 \mathrm{~kg}$ per hectare (Anonymous 2019). Grain yield is a complex polygenic quantitative trait, greatly affected by environment. Hence, assessment of variability for grain and grain yield attributes is essential for the successful yield improvement through breeding programme. Furthermore, the productivity of selection in any breeding programme is founded on the knowledge of character association. Path analysis, which is used to formulate selection indices for genetic improvement, can be used to determine the cause effect of the essential attribute. Hence, the present investigation was undertaken for evaluation of variability, correlation and path analysis in promising sorghum genotypes.

\section{Materials and Methods}

Experiment was conducted at Sorghum Improvement Project, MPKV Rahuri comprised of 44 including two checks i.e. Phule Anuradha and Phule Suchitra during rabi 2019-20 in RBD design with two replication. Observation were recorded on five randomly selected plants for grain yield and yield contributing characters like days to 50\% flowering, days to maturity, plant height $(\mathrm{cm})$, number of internodes per plant, number of green leaves at harvest per plant, panicle length $(\mathrm{cm})$, panicle width $(\mathrm{cm})$, panicle weight $(\mathrm{g}), 1000$ grain weight $(\mathrm{g})$, dry fodder yield per plant $(\mathrm{g})$, harvest index and grain yield per plant $(\mathrm{g})$. Analysis of variance was estimated as per procedure proposed by Panse and Sukhatme (1995). The genotypic and phenotypic coefficients of variation were calculated as per Burton (1952), Heritability in broad sense was estimated as per suggested by Hanson et al., (1956), while genetic advance was estimated as suggested by Johnson et al., (1955). Genotypic and phenotypic correlation coefficients were worked out by adopting method described by Singh and Choudhary (1977), while path coefficient analysis was performed as per Dewey and $\mathrm{Lu}$ (1959).

\section{Results and Discussion}

The analysis of variance for all twelve quantitative traits is presented in Table 1. The mean sum of squares due to genotypes showed highly significant differences for all twelve traits under study at 5\% and $1 \%$ level of significance. This indicated that there is ample scope for selection of promising lines from the present gene pool for grain yield and yield attributing traits.

The result on mean, range, $\mathrm{PCV}, \mathrm{GCV}$, heritability and genetic advance as per cent for yield and yield contributing characters mentioned in Table 2. PCV was higher than GCV for all characters studied showing that all highly influenced by environment. The high magnitude of GCV and PCV were found for number of green leaves at harvest per plant, panicle length, panicle width, panicle weight, harvest index and grain yield per plant. The estimation of genotypic and phenotypic coefficient of variation indicates the amount of genetic and non-genetic variation present for different desirable characters. Higher magnitude of GCV and 
PCV for these traits indicated presence of high degree of variability and better scope for selection. Similar result were observed by Prabhakar (2001), Arunkumar et al., (2004) and Sahil et al., (2016).

For making effective improvement in the trait for which selection is practiced, heritability has been adopted by large number of workers as a reliable indicator. The heritability (b.s.) estimates ranged between 46.80 to 96.30 per cent. All characters showed high heritability except no. of internodes per plant. Dry fodder yield per plant recorded highest heritability $(96.30 \%)$ while number of internodes per plant recorded the moderate estimate $(46.80 \%)$ of heritability. High heritability for days to $50 \%$ flowering was estimated in the present study which was in accordance with Durga et al., (2002) while for trait fodder yield; high heritability was reported by Godharle (2010). High heritability (b.s.) with high genetic advance as present mean was recorded for all characters except days to $50 \%$ flowering, days to maturity and number of internodes per plant, indicate that these traits were predominantly governed by additive gene action and selection of these traits would be more effective for desired genetic improvement. High estimates of heritability and genetic advance as percent mean also reported by Durga et al., (2002) for days to $50 \%$ flowering while the DivyaVaka (2017) reported the high estimates of heritability and genetic advance as percent mean for harvest index.

In general the genotypic correlation was generally of higher magnitude than phenotypic correlation (Table 3), indicating association between various characters studied. The grain yield per plant showed significant and positive relationship at genotypic and phenotypic level with panicle weight $\left(r_{g}=0.990\right.$ and $\left.r_{p}=0.977\right)$ followed by harvest index $\left(r_{g}=0.896\right.$ and $r_{p}=$ $0.893)$, panicle width $\left(r_{g}=0.730\right.$ and $r_{p}=$ $0.659)$, panicle length $\left(r_{g}=0.691\right.$ and $r_{p}=$ $0.682)$, plant height $\left(r_{g}=0.622\right.$ and $\left.r_{p}=0.589\right)$, dry fodder yield/plant $\left(r_{g}=0.595\right.$ and $r_{p}=$ $0.567), 1000$ grain weight $\left(r_{g}=0.502\right.$ and $r_{p}=$ $0.489)$, no. of internodes/plant $\left(r_{g}=0.414\right.$ and $\left.r_{p}=0.236\right)$ and no. of green leaves at harvest per plant $\left(r_{\mathrm{g}}=0.347\right.$ and $\left.\mathrm{r}_{\mathrm{p}}=0.288\right)$ respectively. It indicates dependence of these characters on each other. Similar result were reported by Haris (2001), Sahil et al., (2016) and Shilpa and Kajjidoni (2019). Studies on inter- character association for the yield components traits revealed significant and positive association of days to maturity at both level. Plant height had positive significant correlation with no. of internodes per plant, no. of green leaves per plant, panicle length, panicle width, panicle weight, 1000 grain weight and dry fodder yield per plant. The grain yield per plant showed significant and negative correlation with days to $50 \%$ flowering $\left(r_{g}=-0.249\right.$ and $\left.r_{p}=-0.222\right)$ and days to maturity $\left(r_{g}=-0.244\right.$ and $\left.r_{p}=-0.223\right)$ at genotypic and phenotypic level respectively.

Their association with grain yield per plant was however a significant and positive, indicating a need for balanced selection for these traits while effecting improvement for grain yield.

In path analysis, the highest positive direct effect on grain yield per plant was through harvest index followed by panicle weight, dry fodder yield per plant, days to maturity, no. of internodes per plant, panicle length and plant height (Table 4). The characters, days to $50 \%$ flowering, 1000 grain weight and panicle width had low negative direct effect on grain yield per plant. 
Table.1 Analysis of variance for twelve characters of forty four rabi sorghum genotypes

\begin{tabular}{|c|c|c|c|c|}
\hline Sr.No. & Character & Replication & Genotypes & Error \\
\hline & DF & 1 & 43 & 43 \\
\hline $\mathbf{1}$ & Days to 50 \% flowering & 0.28 & $64.80^{* *}$ & 3.66 \\
\hline $\mathbf{2}$ & Days to maturity & 1.636 & $67.223 * *$ & 1.660 \\
\hline $\mathbf{3}$ & Plant height (cm) & 483.914 & $2279.384 * *$ & 44.218 \\
\hline $\mathbf{4}$ & Number of internodes/plant & 2.124 & $3.289 * *$ & 1.192 \\
\hline $\mathbf{5}$ & Number of green leaves/plant at & 1.378 & $4.291 * *$ & 0.499 \\
\hline $\mathbf{6}$ & harvest & & & \\
\hline $\mathbf{7}$ & Panicle length (cm) & 0.171 & $20.813 * *$ & 0.822 \\
\hline $\mathbf{8}$ & Panicle width (cm) & 4.545 & $2216.246 * *$ & 6.432 \\
\hline $\mathbf{9}$ & Panicle weight $(\mathrm{g})$ & 2.422 & $74.931 * *$ & 1.463 \\
\hline $\mathbf{1 0}$ & 1000 grain weight $(\mathrm{g})$ & $468.28 * *$ & $2184.083 * *$ & 41.44 \\
\hline $\mathbf{1 1}$ & Dry fodder yield /plant $(\mathrm{g})$ & 9.822 & $81.988^{* *}$ & 6.061 \\
\hline $\mathbf{1 2}$ & Harvest index $(\%)$ & 0.557 & $1896.517 * *$ & 72.231 \\
\hline
\end{tabular}

$*, * *=$ significant at $5 \%$ and $1 \%$ levels, respectively

Table.2 Estimation of variability parameters for grain yield and its contributing characters in forty four rabi sorghum genotypes

\begin{tabular}{|c|c|c|c|c|c|c|c|}
\hline $\begin{array}{l}\text { Sr. } \\
\text { No. }\end{array}$ & Character & Mean & Range & $\begin{array}{c}\text { GCV } \\
(\%)\end{array}$ & $\begin{array}{l}\text { PCV } \\
(\%)\end{array}$ & $\begin{array}{c}\text { Heritability } \\
\mathbf{h}^{2}(\mathbf{b s})\end{array}$ & $\begin{array}{l}\text { Genetic } \\
\text { Advance as } \\
\% \text { of Mean }\end{array}$ \\
\hline 1 & $\begin{array}{l}\text { Days to } 50 \% \\
\text { flowering }\end{array}$ & 87.24 & $68.50-94.50$ & 6.34 & 6.71 & 89.30 & 12.34 \\
\hline 2 & Days to maturity & 128.93 & $110.00-136.50$ & 4.44 & 4.55 & 95.20 & 8.93 \\
\hline 3 & Plant height $(\mathrm{cm})$ & 202.62 & $130.83-259.17$ & 16.50 & 16.82 & 96.20 & 33.34 \\
\hline 4 & $\begin{array}{c}\text { Number of } \\
\text { internodes/plant }\end{array}$ & 9.53 & 6.66-11.67 & 10.74 & 15.71 & 46.80 & 15.14 \\
\hline 5 & $\begin{array}{c}\text { No.of green } \\
\text { leaves/plant at harvest }\end{array}$ & 4.33 & $1.67-7.83$ & 31.77 & 35.71 & 79.20 & 58.23 \\
\hline 6 & Panicle length $(\mathrm{cm})$ & 13.25 & $6.50-21.90$ & 23.86 & 24.83 & 92.40 & 47.26 \\
\hline 7 & Panicle width $(\mathrm{cm})$ & 5.11 & $2.67-8.00$ & 24.26 & 27.46 & 78.10 & 44.16 \\
\hline 8 & Panicle weight (g) & 103.43 & $50.00-185.00$ & 31.74 & 32.63 & 94.60 & 63.59 \\
\hline 9 & 1000 grain weight $(\mathrm{g})$ & 31.78 & $18.75-48.10$ & 19.07 & 19.45 & 96.20 & 38.53 \\
\hline 10 & $\begin{array}{l}\text { Dry fodder yield } \\
\text { /plant }(\mathrm{g})\end{array}$ & 190.10 & $124.00-245.50$ & 17.22 & 17.55 & 96.30 & 34.80 \\
\hline 11 & Harvest index (\%) & 24.68 & $11.00-36.75$ & 24.96 & 26.88 & 86.20 & 47.75 \\
\hline 12 & Grain yield / plant (g) & 74.69 & $30.00-147.50$ & 40.43 & 42.01 & 92.70 & 80.18 \\
\hline
\end{tabular}


Table.3 Estimates of genotypic (above diagonal) and phenotype correlation coefficients (below diagonal) among grain yield and yield Contributing characters in forty four rabi sorghum genotypes

\begin{tabular}{|c|c|c|c|c|c|c|c|c|c|c|c|c|}
\hline Character & $\begin{array}{c}\text { Days to } \\
50 \% \\
\text { flowering }\end{array}$ & $\begin{array}{l}\text { Days to } \\
\text { maturity }\end{array}$ & $\begin{array}{c}\text { Plant } \\
\text { height } \\
\text { (cm) }\end{array}$ & $\begin{array}{c}\text { No. of } \\
\text { internodes } \\
\text { / plant }\end{array}$ & $\begin{array}{c}\text { No. of } \\
\text { green } \\
\text { leaves/plant } \\
\text { at harvest }\end{array}$ & $\begin{array}{c}\text { Panicle } \\
\text { length } \\
\text { (cm) }\end{array}$ & $\begin{array}{l}\text { Panicle } \\
\text { width } \\
\text { (cm) }\end{array}$ & $\begin{array}{c}\text { Panicle } \\
\text { weight } \\
\text { (g) }\end{array}$ & $\begin{array}{c}1000 \\
\text { grain } \\
\text { weight } \\
\text { (g) }\end{array}$ & $\begin{array}{c}\text { Dry } \\
\text { fodder } \\
\text { yield / } \\
\text { plant (g) }\end{array}$ & $\begin{array}{c}\text { Harvest } \\
\text { index } \\
(\%)\end{array}$ & $\begin{array}{l}\text { Grain } \\
\text { yield / } \\
\text { plant } \\
\text { (g) }\end{array}$ \\
\hline Days to $50 \%$ flowering & 1.000 & $0.978 * *$ & -0.114 & $0.349 * *$ & 0.029 & $0 . \overline{-}^{-}$ & $-0.369 * *$ & $\frac{-}{0.356 * *}$ & $-0.218 *$ & -0.021 & $-0.268 *$ & $-0.249 *$ \\
\hline Days to maturity & $0.958 * *$ & 1.000 & -0.144 & $0.304 * *$ & 0.028 & - & $-0.355^{* *}$ & $0.347 * *$ & -0.173 & -0.042 & $-0.256^{*}$ & $-0.244^{*}$ \\
\hline Plant height (cm) & -0.109 & -0.140 & 1.000 & $0.720 * *$ & $0.364 * *$ & $0.416 * *$ & $0.495 * *$ & $0.605 * *$ & $0.387 * *$ & $0.977 * *$ & $0.241 *$ & $0.622 * *$ \\
\hline $\begin{array}{c}\text { Number of } \\
\text { internodes/plant }\end{array}$ & 0.139 & 0.164 & $0.526 * *$ & 1.000 & 0.070 & -0.080 & $0.268 * *$ & $0.367 * *$ & $0.333 * *$ & $0.799 * *$ & 0.080 & $0.414 * *$ \\
\hline $\begin{array}{c}\text { Number of green } \\
\text { leaves/plant at harvest }\end{array}$ & 0.043 & 0.03 & $0.325 * *$ & 0.109 & 1.000 & $0.422 * *$ & $0.450 * *$ & $0.352 * *$ & 0.136 & $0.314 * *$ & $0.232 *$ & $0.347 * *$ \\
\hline Panicle length (cm) & $-0.462 * *$ & $-0.455^{* *}$ & $0.400 * *$ & -0.080 & $0.339 * *$ & 1.000 & $0.699 * *$ & $0.709 * *$ & $0.543 * *$ & $0.335^{* *}$ & $0.671 * *$ & $0.691 * *$ \\
\hline Panicle width $(\mathrm{cm})$ & $-0.341 * *$ & $-0.326^{*}$ & $0.446^{* *}$ & 0.114 & $0.308 * *$ & $0.668 * *$ & 1.000 & $0.749 * *$ & $0.559 * *$ & $0.468 * *$ & $0.648 * *$ & $0.730 * *$ \\
\hline Panicle weight (g) & $-0.315 * *$ & $-0.323 * *$ & $0.585 * *$ & $0.215^{*}$ & $0.287 * *$ & $0.698 * *$ & $0.689 * *$ & 1.000 & $0.473 * *$ & $0.565^{* *}$ & $0.897 * *$ & $0.990 * *$ \\
\hline 1000 grain weight $(g)$ & -0.185 & -0.158 & $0.375^{* *}$ & 0.204 & 0.137 & $0.519 * *$ & $0.502 * *$ & $0.471 * *$ & 1.000 & $0.337 * *$ & $0.469 * *$ & $0.502 * *$ \\
\hline Dry fodder yield /plant (g) & -0.017 & -0.040 & $0.975^{* *}$ & $0.563 * *$ & $0.278 * *$ & $0.320 * *$ & $0.421 * *$ & $0.552 * *$ & $0.330 * *$ & 1.000 & 0.195 & $0.595 * *$ \\
\hline Harvest index (\%) & $-0.234^{*}$ & $-0.224^{*}$ & 0.205 & -0.013 & 0.187 & $0.648 * *$ & $0.565^{* *}$ & $0.860 * *$ & $0.41 * *$ & 0.164 & 1.000 & $0.896 * *$ \\
\hline Grain yield / plant (g) & $-0.222 *$ & $-0.223^{*}$ & $0.589 * *$ & $0.236 *$ & $0.288 * *$ & $0.682 * *$ & $0.659 * *$ & $0.977 * *$ & $0.489 * *$ & $0.567 * *$ & $0.893 * *$ & 1.000 \\
\hline
\end{tabular}

*and ** significant at $\mathbf{P}=5$ and $\mathbf{P}=1$ level of significance, respectively 
Table.4 Estimates of genotypic direct (diagonal) and indirect effects (above and below diagonal) of component characters on grain yield in forty four rabi sorghum genotypes

\begin{tabular}{|c|c|c|c|c|c|c|c|c|c|c|c|c|}
\hline Character & $\begin{array}{c}\text { Days to } \\
50 \% \\
\text { flowering }\end{array}$ & $\begin{array}{l}\text { Days to } \\
\text { maturity }\end{array}$ & $\begin{array}{l}\text { Plant } \\
\text { height } \\
\text { (cm) }\end{array}$ & $\begin{array}{c}\text { No. of } \\
\text { internodes } \\
\text { / plant }\end{array}$ & $\begin{array}{c}\text { No. of } \\
\text { green } \\
\text { leaves/plant } \\
\text { at harvest }\end{array}$ & $\begin{array}{l}\text { Panicle } \\
\text { length } \\
(\mathrm{cm})\end{array}$ & $\begin{array}{l}\text { Panicle } \\
\text { width } \\
\text { (cm) }\end{array}$ & $\begin{array}{l}\text { Panicle } \\
\text { weight } \\
\text { (g) }\end{array}$ & $\begin{array}{c}1000 \\
\text { grain } \\
\text { weight } \\
\text { (g) }\end{array}$ & $\begin{array}{c}\text { Dry } \\
\text { fodder } \\
\text { yield / } \\
\text { plant (g) }\end{array}$ & $\begin{array}{c}\text { Harvest } \\
\text { index } \\
(\%)\end{array}$ & $\begin{array}{c}\text { Genotypic } \\
\text { correlation with } \\
\text { grain yield / } \\
\text { plant (g) }\end{array}$ \\
\hline Days to $50 \%$ flowering & -0.172 & 0.150 & 0.000 & 0.043 & 0.001 & -0.032 & 0.013 & -0.108 & 0.011 & -0.005 & -0.150 & $-0.249 *$ \\
\hline Days to maturity & -0.168 & 0.153 & -0.001 & 0.038 & 0.001 & -0.031 & 0.013 & -0.105 & 0.009 & -0.009 & -0.143 & $-0.244^{*}$ \\
\hline Plant height (cm) & 0.020 & -0.022 & 0.004 & 0.089 & 0.010 & 0.027 & -0.018 & 0.184 & -0.020 & 0.213 & 0.135 & $0.622 * *$ \\
\hline $\begin{array}{c}\text { Number of } \\
\text { internodes/plant }\end{array}$ & -0.060 & 0.047 & 0.003 & 0.123 & 0.002 & -0.005 & -0.010 & 0.111 & -0.017 & 0.174 & 0.045 & $0.414 * *$ \\
\hline $\begin{array}{c}\text { Number of green } \\
\text { leaves/plant at harvest }\end{array}$ & -0.005 & 0.004 & 0.001 & 0.009 & 0.028 & 0.028 & -0.016 & 0.107 & -0.007 & 0.069 & 0.130 & $0.347 * *$ \\
\hline Panicle length (cm) & 0.084 & -0.072 & 0.002 & -0.010 & 0.012 & 0.066 & -0.025 & 0.215 & -0.028 & 0.073 & 0.375 & $0.691 * *$ \\
\hline Panicle width (cm) & 0.064 & -0.055 & 0.002 & 0.033 & 0.012 & 0.046 & -0.036 & 0.227 & -0.028 & 0.102 & 0.363 & $0.730 * *$ \\
\hline Panicle weight (g) & 0.061 & -0.053 & 0.002 & 0.045 & 0.010 & 0.047 & -0.027 & 0.304 & -0.024 & 0.123 & 0.502 & $0.990 * *$ \\
\hline 1000 grain weight (g) & 0.038 & -0.027 & 0.002 & 0.041 & 0.004 & 0.036 & -0.020 & 0.144 & -0.051 & 0.073 & 0.263 & $0.502 * *$ \\
\hline Dry fodder yield /plant (g) & 0.004 & -0.006 & 0.004 & 0.099 & 0.009 & 0.022 & -0.017 & 0.172 & -0.017 & 0.218 & 0.109 & $0.595 * *$ \\
\hline Harvest index (\%) & 0.046 & -0.039 & 0.001 & 0.010 & 0.006 & 0.044 & -0.023 & 0.272 & -0.024 & 0.043 & 0.560 & $0.896 * *$ \\
\hline
\end{tabular}

$*$, ** = significant at $5 \%$ and $1 \%$ levels, respectively $\quad$ Residual effect $(\mathbf{R})=0.080$

Bold figures indicate direct effect 
By considering the overall indirect effect of all characters, days to $50 \%$ flowering, days to maturity, plant height, no. of internodes/plant, no. of green leaves/plant at harvest, panicle length, panicle width, panicle weight, 1000 grain weight, dry fodder yield/plant and harvest index contributed indirectly towards grain yield per plant. Similar results were revealed by Haris (2001) and Mahajan et al., (2011).

Result of present research study on genetic variability, correlation and path analysis studies reflects that scope for improvement of grain yield and its component through selection of plant height, 1000 grain weight, panicle length and panicle width as they recorded moderate to high $\mathrm{PCV}, \mathrm{GCV}$, heritability, genetic advance as per cent of mean in addition to correlation and direct effect of the traits with grain yield indicating its effectiveness as important selection criteria for yield improvement.

\section{Acknowledgment}

This is a part of research work of M.Sc. thesis carried out by M. S. Nikam and submitted to Mahatma Phule Krishi Vidyapeeth, Rahuri. The authors are grateful to the Department of Agricultural Botany, M.P.K.V., Rahuri and Sorghum Improvement Project, M.P.K.V., Rahuri for facility provided and supply of seed material of rabi sorghum genotypes for present study.

\section{References}

Anonymous, 2019. Fourth advance estimates of area, production and productivity of crops in respect of Maharashtra state for the year 2019-20.

Arunkumar, B., Biradar, B. D. and Salimath, P. M. 2004. Genetic variability and character association studies in rabi sorghum. Karnataka J. Agri. Sci., 17
(3) : 471-475.

Burton, G. W. 1952. Quantitative inheritance in grasses Proc. Sixth International Grassland Cong. $1: 277-283$.

De Candolle, A. 1884. Origin of cultivated plants, Hafner Publishing Company, New York.

Dewey, D. R. and Lu, H. K. 1959. A correlation and path analysis of components of crested wheat grass seed production. Agron. J. 51 (6) : 515-518.

DivyaVaka. 2017. Genetic divergence in rabi sorghum (Sorghum bicolor (L.) Moench) M.Sc. (Agri.) Thesis submitted to Acharya N. G. Ranga Agricultural University, Rajendranadgar, Hyderabad.

Durga, K. K., Reddy, B. V. S., Reddy, M. S. S. and Ganesh, M. 2002. Variability studies for various disease related parameters and yield contributing characters of sorghum. Agric. J. Digest., 22 (3) : 141-144.

Godbharle, A. R., More, A. W. and Ambekar, S. S. 2010. Genetic variability and correlation studies in elite ' $B$ ' and ' $R$ ' lines in kharif sorghum. Electron. J. Plant Breed., 1(4): 989-993.

Hanson, G. H., Robinson, H. F. and Comstock, R. E. (1956). Biometrical studies in segregating populations of Korean lespeds. Agron. J., 48:268-272.

Haris. 2001. Estimation of genetic diversity in germplasm collections of rabi sorghum (Sorghum bicolor (L.) Moench). Thesis submitted to the University of Agricultural Sciences, Dharwad.

Johnson II. W., Robinson, H. F. and Comstock, R. E. 1955.Estimates of genetic and environment variability in soybean.Agron. J., pp:314-318.

Panse, V. G. and Sukhatme, P. V. 1995. Statistical methods for agricultural workers, ICAR, New Delhi.4" Edn.

Prabhakar. 2001. Variability, heritability, 
genetic advance and character association in rabi sorghum. $J$. Maharashtra Agric. Univ., 26(2) : 188189.

Rana, C. R., Swarnalata, K. and Rao, M. H. 1997. Impact of genetic improvement on sorghum productivity in India. In Proceeding of an International Conference on the Genetic Improvement of Sorghum and Pearl Millet, held at Lubbock, Texas, 22-27 September 1996. International Sorghum and Millet Research (INTSORMIL) International Crops Research Institute for the Semi-arid Tropics (ICRISAT), pp. 142-165.

Mahajan, R. C., Wadikar, P. B., Pole, S. P. and Dhuppe, M. V. 2011. Variability, correlation and path analysis studies in sorghum. Res. J. Agric. Sci., 2(1): 101103.

Sahil A. I., Sabiel, Ibrahim Noureldin, Shahbaz K. Baloch, Sana Ullah Baloch and Waseem Bashir. 2016. Genetic variability and estimates of heritability in sorghum (Sorghum bicolour (L.) Monech) genotypes grown in a semiarid zone of Sudan. Arch. Agron. Soil Sci., 62:1,139-145.

Shilpa, V. and Kajjidoni, S. T. 2019. Characters association and path analysis studies in germplasm lines of rabi sorghum (Sorghum bicolor (L.) Monech). I. J. C. S., 7(1): 2309-2313.

Singh, R. K. and Choudhary, B. D. 1977. "Biometrical Methods in Quantitative Genetic Analysis. "Kalyani Publishers, New Delhi., pp. 39-68.

\section{How to cite this article:}

Nikam, M. S., G. C. Shinde, V. R. Awari, M. S. Shinde and Kute, N. S. 2021. Genetic Variability, Correlation and Path Analysis Studies in Rabi Sorghum (Sorghum bicolour (L.) Moench) Genotypes. Int.J.Curr.Microbiol.App.Sci. 10(10): 185-192. doi: https://doi.org/10.20546/ijcmas.2021.1010.021 